\title{
ANALISIS STRATEGI PEMASARAN DALAM UPAYA MENINGKATKAN MINAT PEMBELIAN PT. EMMA TOUR AND TRAVEL
}

\section{Tengku Kespandiar}

Fakultas Ekonomi dan Bisnis, Universitas Negeri Malang, Jawa Timur, Indoensia

Email: Tengku.kespandiar.2004139@students.um.ac.id

\begin{tabular}{ll}
\hline INFO ARTIKEL & ABSTRAK \\
\hline Diterima & Penelitian ini bertujuan untuk mengetahui dan identifikasi: (1) Strategi \\
12 November 2021 & pemasaran yang diterapkan PT. Emma Tour And Travel dalam upaya \\
Direvisi & meningkatkan minat pembelian, (2) Analisis minat pembelian Pada PT. \\
15 November 2021 & Emma Tour And Travel. (3) kendala yang dihadapi PT. Emma Tour And \\
Disetujui & Travel. Penelitian ini menggunakan metode deskriftif kualitatif \\
20 Januari 2022 & merupakan penelitian survey, Karena penelitian ini memberikan \\
\hline Kata Kunci: & gambaran yag jelas sistematis dalam mengenai strategi pemaasaran PT. \\
Strategi & Emma Tour And Travel Banjarmasin dan cara penelitian metode \\
Pemasaran; Minat & dokumentasi, observasi, wawancara. Berdasarkan Hasil penelitian \\
Pembelian; Tour & Strategi Pemasaran 4P (Product, Price, Place, Promotion) dalam \\
And Travel & meningkatkan minat pembelian konsumen yang diterapkan oleh PT. \\
& $\begin{array}{l}\text { Emma Tour And Travel Malang menggunakan Startegi yaitu pada } \\
\text { produk, harga, promosi,dan tempat dan hasil penelitian diketahui bahwa }\end{array}$ \\
& rata-rata yang menjadi alasan konsumen melakukan pembelian di PT. \\
& Emma Tour And Travel Malang adalah karena harga, dan pelayanan \\
& yang diberikan. Hal ini mengidentifikasi para pemimpin agar memahami \\
& apa yang dapat meningkatkan minat pembelian agar lebih memperhatikan \\
& variable-variabel tersebut.
\end{tabular}

Keywords:

Marketing

\section{ABSTRACT}

This study aims to identify and analyze: (1) The marketing strategy applied by PT. Emma Tour And Travel in an effort to increase purchase interest, (2) Buying interest analysis at PT. Emma Tours And Travels. (3) the obstacles faced by PT. Emma Tours And Travels. This study uses a qualitative descriptive method is a survey research, because this research provides a clear and systematic description of the marketing strategy of PT. ocean star space tour and travel Banjarmasin. and research methods documentation, observation, interviews. Based on the results of the research on the 4P Marketing Strategy (Product, Price, Place, Promotion) in increasing consumer buying interest implemented by PT. Emma Tour And Travel Malang uses a strategy that is on products, Strategy; Purchase Interest; Tour And Travel prices, promotions, and places. And the results of the study found that the average reason for consumers to make purchases at PT. Emma Tour And Travel Malang is because of the price, and the service provided. This identifies the leaders in order to understand what can increase purchase intention in order to pay more attention to these variables.

\section{Pendahuluan}

$\begin{array}{ll}\text { How to cite: } & \text { Kespandiar, T., (2022). Analisis Strategi Pemasaran dalam Upaya Meningkatkan Minat Pembelian } \\ & \text { PT. Emma Tour and Travel, Jurnal Syntax Transformation, 3(1). } \\ & \text { https://doi.org/10.46799/jst.v3i1.499 } \\ \text { E-ISSN: } & 2721-2769 \\ \text { Published by: } & \text { Ridwan Institute }\end{array}$


Era globalisasi saat ini dalam persaingan bisnis sangat ketat, selain daripada itu dengan adanya pandemi covid-19 dimana setiap perusahaan mengalami dampaknya dikarnakan pusat pariwisata banyak yang ditutup pada masa pandemi. Namun setelah adanya new normal tempat wisata dapat beroperasi kembali dengan syarat mengikuti protokol kesehatan. Fenomena tersebut persaingan perusahaan sangat dituntut bekerja keras untuk dapat memenuhi kebutuhan konsumen serta berusaha untuk menciptakan produk / jasa yang memiliki keunggulan dan menciptakan produk / jasa yang berbeda dengan pesaing. Maka membuatnya dapat bertahan di pasar, dalam menarik konsumen, serta mampu meningkatkan pembelian. Keunggulan dalam bersaing akan membangun kemampuan untuk meningkatkan performa yang lebih efektif dari pesaing.

PT. Emma Tour And Travel merupakan salah satu bidang yang bergerak dibidang jasa yang menyediakan atau melayani berbagai hal yang dibutuhkan sebelum melakukan perjalanan. Oleh karena itu industri jasa pariwisata pada saat ini merupakan bisnis yang cukup menjanjikan, karena setiap masyarakat memerlukan liburan atau bepergian untuk kepentingan tertentu.

Strategi pemasaran dan promosi merupakan aspek yang paling penting dalam menjual sebuah produk. Strategi pemasaran yang paling mendasar adalah kinerja yang efisien, efektif dan professional. Tetapi bila strategi tidak benar hanya membuang-buang biaya dan tidak mencapai sasaran ke calon pelanggan merupakan upaya yang sia-sia (Nugroho, 2012).
Menurut (Pearce II, 2008) strategi merupakan rencana berskala besar, dengan orientasi masa depan, guna berinteraksi dengan kondisi persaingan untuk mencapai tujuan. Strategi merupakan perencanaan induk yang komprehensif, yang menjelaskan bagaimana perusahaan akan mencapai semua tujuan yang telah ditetapkan berdasarkan misi yang telah ditetapkan sebelumnya (Freddy, 2016)

Menurut penulis strategi pemasaran akan mempengaruhi minat konsumen untuk membeli apabila strategi pemasaran yang dirumuskan dengan promosi, harga, produk, dan tempat memiliki atribut yang sesuai dengan keinginan konsumen maka minat konsumen atau keputusan konsumen untuk membeli akan terbentuk.

Menurut (Stanton, 2015) adalah sesuatu yang meliputi seluruh sistem yang berhubungan dengan tujuan untuk merencanakan dan menentukan harga sampai dengan mempromosikan dan mendistribusikan barang dan jasa yang bisa memuaskan kebutuhan pembeli aktual maupun potensial, jadi apabila disimpulkan dari beberapa definisi diatas maka strategi pemasaran adalah gabungan dari kegiatan yang direncanakan dan reaksi untuk mengantisipasi persaingan dan perkembangan yang tidak terduga.

Menurut (Tjiptono, 2008) minat konsumen tumbuh karena suatu motif berdasarkan atribut-atribut sesuai dengan keinginan dan kebutuhan dalam menggunakan suatu produk, berdasarkan hal tersebut maka perusahaan harus tepat merancang strategis pemasaran untuk menarik minat dari diri konsumen agar tertarik terhadap produk barang yang ditawarkan sehingga apabila konsumen 
telah berminat pada produk tersebut maka akan ada keputusan untuk membeli tersebut. Menurut (Durianto, 2010) yaitu "pembelian nyata merupakan sasaran akhir konsumen dimana minat beli merupakan pernyataan mental konsumen yang merefleksikan perencanaan untuk membeli sejumlah produk dengan merek tertentu, pengetahuan akan produk yang akan dibeli sangat diperlukan oleh konsumen".

Berdasarkan latar belakang diatas, dimana begitu pentingnya strategi pemasaran terhadap meningkatkan minat pembelian, maka penulis tertarik untuk membahas dan menuangkannya dalam penelitian yang berjudul "Analisi Strategi Pemasaran Dalam Upaya Meningkatkan Minat Pembelian (Studi Pada PT. Emma Tour And Travel Malang)".

\section{Metode Penelitian}

Penelitian ini menggunakan jenis penelitian deskriptif dengan pendekatan kualitatif yang bertujuan untuk mengetahui, mendeskripsikan dan menjelaskan keadaan sebenarnya terkait tentang strategi pemasaran dalam upaya meningkatkan minat pembelian pada PT. Emma Tour And Travel Malang. Teknik pengumpulan data melalui observasi, dokomentasi dan wawancara (Sugiyono, 2007). Dalam penelitian ini penulis mengambil objek yang dilakukan pada PT. Emma Tour And Travel Malang, Jalan Brigjend Slamet Riadi Nomor 173 B Klojen, Oro-oro Dowo, Kec. Klojen, Kota Malang, Jawa Timur 65112. Teknik analisis data yang diperoleh di lapangan akan di analisis dengan cara membandingkan data-data yang diperoleh dari teori, prinsip dan gagasan yang terkumpul pada penelitian kepustakaan (Krippendoff,1993). Selanjutnya diklarifikasi, diteliti dan ditelaah untuk menjawab permasalahan yang telah dirumuskan secara deskriptif kualitatif setelah itu dirangkum dalam suatu kesimpulan (Suryabrata, 1998).

\section{Hasil dan Pembahasan}

1. Strategi pemasaran merupakan bauran pemasaraan atau sekumpulan alat pemasaran yang digunakan oleh perusahaan untuk mencapai tujuan pemasarannya dalam sasaran. Kemudian dengan adanya strategi marketing mix diharapkan akan mempermudah pihak PT. Emma Tour And Travel dalam memasarkan jasanya. Berdasarkan hasil yang diperoleh dapat dijelaskan pembahasan mengenai Penerapan Strategi pemasaran pada PT. Emma Tour And Travel Malang dalam upaya meningkatkan minat pembeli dilihat dari 4P yaitu sebagai berikut :

a) Strategi produk

Strategi produk jasa biro travel dan tour pada PT. Emma Tour And Travel Malang. beberapa produk jasa yang pertama paket wisata misalkan domestik atau internasional, ada paket student, family, melayani ticketing pesawat, study banding untuk dinas ataupun instansi, study tour untuk para pelajar sehingga tujuannya untuk semua kalangan. Strategi yang paling diutamakan oleh PT. Emma Tour and Travel Malang yaitu kemasan PT. Emma Tour and Travel dengan memberikan pelayanan dan fasilitas yang didapat oleh konsumen. Produk yang ditawarkan merupakan produk 
jasa oleh karena itu dalam menjalankan bisninya perlu memperhatikan layanan yang dilakukan oleh karyawan kepada konsumen dan memastikan karyawan sudah melakukan tugasnya dengan baik dalam melayani konsumen, pelayanan kepada konsumen yang lebih di perhatikan dalam strategi produk yang dilakukan perusahaan. Kemudian target pasar yaitu semua kalangan masyrarakat yang membutuhkan jasa tour dan travel. Menurut (Sugiyono, 2015) kualitas jasa tour dan travel, dalam produk jasa PT. Emma Tour and Travel berupa fasilitas melayani ticketing, pembuatan paspor, visa, study banding untuk dinas ataupun instansi, study tour untuk pelajar mulai SD, SMP, SMA dan SMK sehingga tujuannya untuk semua kalangan.

b) Strategi harga

Harga adalah sejumlah uang sebagai alat tukar untuk memperoleh produk dan jasa. Berdasarkan pemaparan (Agustina et al., 2018) penetapan harga jasa merupakan hal penting karena terkait dengan pendapatan (revenue), citra, kualitas, distribusi, dll. Salah dalam menentukan harga akan berakibat fatal terhadap produk yang ditawarkan, sebagai usaha dibidang tour dan travel tentu sangat memikirkan prinsip dan politik ekonomi. Berdasarkan sudut pandang pengusaha, kegiatan ekonomi secara umum bisa diartikan dengan mendapatkan hasil sebanyakbanyaknya dengan modal seminimal mungkin dan terjadinya saling suka sama suka dan kerelaan antara pihak perusahaan dan pihak konsumen tersebut bisa diaplikasikan dalam berbagai bentuk dan prinsip tersebut kiranya bermanfaat untuk mengendalikan laju usaha.

PT. Emma Tour And Travel Malang berfokus pada harga, karena salah satu aspek penting dalam meningkatkan marketing mix. Harga sangat menentukan laku tidaknya produk dan jasa tour dan travel. Sehingga untuk harga pada PT. Emma Tour And Travel Malang sesuai dengan harga penerbangan, PO (perusahaan Outubus), dan tempat wisata atau tujuan dan bisa juga sesuai budget yang dimiliki konsumen dan keinginan konsumen sehingga dapat menyesuaikan. Selanjutnya adanya diskon dengan membuat kontrak dengan pihak terkait seperti (hotel, agen penerbangan, restaurant, $\mathrm{PO}$, wisata) sehingga nantinya bisa mendapatkan diskon harga, sehingga harga dapat bersaing tanpa mengurangi pelayanan pada konsumen PT. Emma Tour And Travel, adapun potongan khusus pada hari libur dan hari besar lainnya.

Hal ini sesuai dengan teori (Tjiptono, 2008) keputusan bauran harga berkenaan dengan kebjikan strategis dan taktis seperti daftar harga, potongan harga khusus, periode pembayaran, diskon, syarat pembayaran dan tingkat diskiminasi harga diantara berbagai kelompok pelanggan. Harga merupakan satuan nilai uang yang dibayarkan sebagai pengganti barang atau jasa yang dihasilkan atas dasar kedua belah pihak. Dari pengertian diatas menjelaskan bahwa harga merupakan 
alat ukur yang dinyatakan dalam bentuk uang, dimna pembeli dapat memperoleh barang dan jasa setelah dia bersedia mengeluarkan sejumlah uang tertentu. Disamping strategi penururnan harga yang pas untuk konsumen bagaimanapun konsumen memiki pemikiran yang sama dengan pengusaha yaitu yang ingin mendapatkan fasilitas dan pelayanan yang bagus dan memuaskan dengan harga yang sangat minimal.

c) Strategi tempat (place)

Untuk sebagai pemilihan tempat usaha dan pemilihan tempat untuk pelayanan kegiatan wisata. Tempat dalam jasa juga merupakan gabungan antara lokasi dan keputusan atas saluran distribusi, dalam hal ini berhubungan dengan bagaimana cara penyampaian jasa kepada konsumen dan dimana lokasi yang strategis. Sehingga tempat juga penting sebagai lingkungan dimana dan bagaimana jasa akan diserahkan, sebagaimna dari nilai dan manfaat dan jasa. Tempat itu strategis karna bisa terjangkau oleh masyarakat, tempat dekat dengan bank BTPN, tempat dekat dengan perumahan dan tempat dekat dengan jalan besar. Selain itu untuk saluran distribusi, tempat wisata juga banyak tujuannya dan sudah menyiapkan tempat peristirahatan juga sesuai dengan pelanggan atau konsumen dan untuk transportasi sudah ada di daerah tujuan.

d) Strategi promosi

Promosi bukan saja berfungsi sebagai alat komunikasi antara perusahaan dengan pelanggan, melainkan juga sebagai alat untuk mempengaruhi pelanggan. Strategi promosi yang digunakan pada usaha ini adalah Penjualan Personal (Personal Selling) (Susanti \& Gunawan, 2019). Penjualan personal adalah komunikasi langsung (tatap muka antara penjual dan calon pelanggan untuk memperkenalkan suatu produk kepada calon pelanggan dan membentuk pemahaman terhdap produk sehingga mereka kemudia akan mencoba membelinya menurut (Tjiptono, 2019).

PT. Emma Tour And Travel mempromosikan paket tour dan travel selalu mengutamakan kelebihan produknya yang akan dijual, pelayanan, promo harga dan fasilitas agar calon konsumen tertarik menggunakan jasa PT. Emma Tour And Travel dan di lain waktu akan menggunakan jasa ini. Promosi merupakan salah satu aspek yang penting dalam manajemen pemasaran, tujuan dari promosi adalah: (1) Produk suatu perusahaan secara otomatis segera diketahui oleh orang banyak setelah di produksi. (2) Suatu perusahaan selalu ingin agar dikenal sebagai perusahaan yang terpercaya. (3) Perusahaan harus mengutamakan kelebihan produk, kualitas pelayanan dan fasilitas, serta profesionalitas karyawan perusahaan supaya diketahui masyarakat. (4) Tujuan yang paling utama adalah untuk meningkatkan penjualan.

Berikut ini cara-cara promosi yang dilakukan PT. Emma Tour And Travel dan solusinya yang terdiri dari:

a) Sales Promotion Pada dasarnya promosi adalah kegiatan pemasaran 
selain personal selling, advertising, publikasi, dan public relation. Kegiatan promosi penjualan meliputi: pertunjukan, pameran, dan sebagainya. Cara promosi penjualan ini dapat mendorong konsumen untuk berminat membeli produk baru. Promosi penjualan yang dilakukan PT. Emma Tour And Travel Malang untuk mencapai tujuannya adalah sebagai Mendorong minat konsumen untuk mencoba produk baru, Meningkatkan penjualan pada saat musim liburan Selain promosi penjualan yang diarahkan pada konsumen, promosi juga lebih diarahkan kepada promosi dagang. Karena ada anggapan bahwa promosi dagang dapat membangkitkan semangat pihak perantara atau agen perjalanan dalam mempromosikan paket wisata dengan mengikuti event dari potongan harga khusus. Selain itu dapat merangsang untuk mendorong penjualan paket Tour and. Travel dengan harapan para konsumen mempunyai keinginan untuk melakukan pembelian jasa pada tour dan travel.

b) Mulut ke mulut (word to mouth) dianggap oleh banyak orang sebagai cara paling efektif untuk mempromosikan . karna bahwa lebih dari 90 persen konsumen mengunakan rekomendasi dari teman atau keluarga ketika memilih produk atau layanan.

c) Penggunaan promosi pada media social adalah bentuk bisnis online yang popular dan murah. facebook, instragram, whatsapp. Akan tetapi kegiatan promosi dimedia social ini hanya dilakukan pada akun sosmed pemilik perusahan saja. Promosi media sosial bisa efektif dalam menjangkau pelanggan apabila karyawan juga ikut andil dalam mempromisikan serta pengelolaan postingannya terlihat menarik di media sosial yang digunakan (Kotler, 2008). Baik itu dengan famplet dan video promosi dari produk atau layanan perusahaan. serta menggunakan influencer dalam promosinya yang banyak digunakan oleh perusahaan lain dan semakin populer melalu media sosial. Dan untuk membangun inisiatif, dan semangat karyawan agar lebih meningkatkan promosi akan lebih baik jika pimpinan memberikan bonus untuk karyawan yang telah mencapai target penjualan.

Hasil penelitian ini didapat bahwa rata-rata yang menjadi alasan konsumen melakukan keputusan pembelian dikarenakan harga yang kompetitif, pelayanan dan fasilitas diberikan serta potongan harga/ diskon yang ditawarkan perusahaan.

2. Minat pembelian PT. Emma Tour And Travel

Proses ini dimulai dari munculnya kebutuhan akan suatu produk atau merek (need arousal), kemudian pemprosesan informasi oleh konsumen (consumer information processing), Maka didapat Hasil penelitian pada minat beli konsumen paling tinggi pada indikator pertama yaitu tertarik untuk mencari informasi mengenai produk, kemudian indikator ke dua yaitu mempertimbangkan untuk membeli, kemudian indikator ke tiga 
yaitu tertarik untuk mencoba, kemudian indikator ke empat yaitu ingin mengetahui produk, kemudian indikator ke lima yaitu ingin memiliki (Kanuk, 2007).

Kecendrungan para konsumen akan meningkat minat beli nya saat liburan, hari besar lainnya, promo harga dan sebagainya. Akan tetapi minat pembelian pada PT. Emma Tour And Travel mengalami penurunan pelanggan pada tahun 2020 bulan Mei hingga sekarang karena adanya bencana skala nasional yaitu wabah virus Covid 19 yang diumumkan pemerintah serta pelarangan mudik dan bepergian keluar kota maupun keluar negeri. membuat pemerintah mengambil tindakan untuk menghentikan sementara layanan Transportasi udara komersial dan cater guna menekan penyebaran virus.

3. Kendala yang dihadapi

Setiap kegiatan pemasaran pasti akan mengalami hambatan dalam memasarkan produknya. Kendala yang dihadapi PT Samudra Bintang Angkasa dalam meningkatkan minat pembelian yaitu.

a. Online ticketing dengan metode pembayaran melalui payment later atau kartu kredit susah di akses. Sehingga untuk meningkatan kan pelayanan dengan metode online tiket sehingga dapat memudahkan konsumen yang ingin memesan tiket tanpa tatap muka atau karna kendala jarak (Purwanto, 2008).

b. Kurangnya promosi yang diatur oleh PT. Emma Tour And Travel pada media social dikarenakan hanya pemimpin yang melakukan kegiatan promosi tidak di imbangi dengan karyawan. Promosi tidak dilakukan dibanyak tempat karena terkendala situasi wabah covid 19 yang sekarang ini dalam masa pembatasan social berskala besar (PSBB). Sehingga untuk meningkatkan pembelian, seharusnya karyawan juga mempromosikan di sosial media mereka untuk produk jasa dan paketan yang ditawarkan perusahaan.

\section{Kesimpulan}

Berdasarkan data yang di peroleh selama pengamatan di PT. Emma Tour And Travel dapat disimpulkan bahwa jasa pelayanan yang ditawarkan oleh PT. Emma Tour And Travel. Dalam meberikan pelayanan dan fasilitas terbaik dan bersaing kepada para konsumennya agar merasa nyaman dan puas ketika menggunakan jasa PT. Emma Tour And Travel.

Strategi pemasaran yang digunakan oleh perusahaan untuk mencapai tujuan pemasarannya dalam sasaran yaitu: (a) Strategi produk Strategi yang paling diutamakan oleh PT. Emma Tour And Travel yaitu kemasan dengan memberikan pelayanan dan fasilitas yang didapat oleh konsumen. paketan wisata domestik atau internasional, ada paket student, family, melayani ticketing pesawat, study banding untuk dinas ataupun instansi, study tour untuk para pelajar sehingga tujuannya untuk semua kalangan. (b) Strategi harga Harga sangat menentukan laku tidaknya produk dan jasa tour dan travel. Sehingga untuk harga sesuai dengan Harga penerbangan, PO 
(perusahaan Outubus), dan tempat wisata atau tujuan dan bisa juga sesuai budget yang dimiliki konsumen dan keinginan konsumen sehingga dapat menyesuaikan. Memberikan diskon harga pada hari libur dan hari besar lainnya. (c) Strategi tempat (place) Strategi Tempat dalam jasa juga merupakan gabungan antara lokasi dan keputusan atas saluran distribusi, dalam hal ini berhubungan dengan bagaimana cara penyampaian jasa kepada konsumen dan lokasi yang strategi untuk saluran distribusi dan tempat perusahaan. (d) Strategi promosi Promosi bukan saja berfungsi sebagai alat komunikasi antara perusahaan dengan pelanggan, melainkan juga sebagai alat untuk mempengaruhi pelanggan. Strategi promosi yang digunakan pada usaha ini adalah Penjualan Personal (Personal Selling), sales promotion dan dari mulut ke mulut. Promosi media sosial bisa efektif dalam menjangkau pelanggan apabila karyawan juga ikut andil dalam mempromosikan serta pengelolaan postingannya terlihat menarik di media sosial yang digunakan. Baik itu dengan famplet dan video promosi dari produk atau layanan perusahaan serta menggunakan influencer dalam promosinya dan untuk membangun inisiatif dan semangat karyawan agar lebih meningkatkan promosi akan lebih baik jika pimpinan memberikan bonus untuk karyawan yang telah mencapai target penjualan.

Penelitian ini memperoleh hasil bahwa rata-rata yang menjadi alasan konsumen melakukan keputusan pembelian dikarenakan harga yang kompetitif, pelayanan dan fasilitas diberikan serta potongan harga/ diskon yang ditawarkan perusahaan.
Proses ini dimulai dari munculnya kebutuhan akan suatu produk atau merek, kemudian pemrosesan informasi oleh konsumen kecenderungan para konsumen akan meningkat minat belinya saat liburan, hari besar lainnya, promo harga dan sebagainya. Akan tetapi minat pembelian pada PT. Emma Tour And Travel mengalami penurunan pada tahun 2020 bulan April hingga sekarang karena adanya bencana skala nasional yaitu wabah virus Covid 19.

Kendala yang dihadapi PT. Emma Tour And Travel dalam meningkatkan minat pembelian yaitu; (a) Online ticketing dengan metode pembayaran melalui payment later atau kartu kredit yang susah di akses. (b) Kurangnya promosi yang diatur oleh PT. Emma Tour And Travel pada media sosial.

\section{BIBLIOGRAFI}

Agustina, N. A., Sumowo, S., \& Wijayantini, B. (2018). Pengaruh Kualitas Produk, Citra Merek, Dan Harga Terhadap Keputusan Pembelian. Jurnal Penelitian IPTEKS, 3(2), 186-196.Google Scholar

Durianto, D. (2010). Strategi Menaklukan pasar melalui riset ekuitas dan perilaku merek. PT.Gramedia Pustaka Utama. Google Scholar

Freddy, R. (2016). ANALISIS SWOT: Teknik Membedah Kasus Bisnis Cara Perhitungan Bobot, Rating, dan OCAI. PT. Gramedia. Jakarta. Google Scholar

Kanuk, S. dan. (2007). Perilaku Konsumen. Indeks. Google Scholar

Kotler, K. (2008). Manajemen Pemasaran. Erlangga. Google Scholar

Krippendoff, K. (1993). Analisis Isi: Pengantar Teori dan Metodologi. Citra Niaga Rajawali Press. Google Scholar 
Nugroho, O. G. Y. P. (2012). Strategi pemasaran paket wisata di biro perjalanan cv. Vienna utama tour karanganyar. Google Scholar

Pearce II, J. A. dan R. R. B. J. (2008). Manajemen Strategis 10. Salemba Empat.

Purwanto. (2008). Manajemen Strategi. CV Ryama Widya. Google Scholar

Stanton. (2015). Prinsip Pemasaran. Cetakan Ketujuh. Erlangga.

Sugiyono. (2007). Metode Penelitian Kuantitatif Kualitatif dan R \& D. Elfabeta. Google Scholar

Sugiyono. (2015). Metode Penelitian
Pendidikan Pendekatan Kuantitatif, Kualitatif, dan R \& D. Alfabeta. Google Scholar

Suryabrata, S. (1998). Metodologi Penelitian. PT Rajagrafindo Perasada. Google Scholar

Susanti, F., \& Gunawan, A. C. (2019). Pengaruh Bauran Promosi Dan Harga Terhadap Keputusan Pembelian Produk Kosmetik Maybelline Di Kota Padang. Google Scholar

Tjiptono, F. (2008). Strategi Pemasaran. CV. Andi Offse. Google Scholar

Tjiptono, F. (2019). Strategi pemasaran. Google Scholar

\section{Copyright holder :}

Tengku Kespandiar (2022)

First publication right :

Jurnal Syntax Transformation

This article is licensed under: 